BBA 659 I 8

\title{
PURIFICATION AND PROPERTIES OF GLUTATHIONE REDUCTASE OF HUMAN ERYTHROCYTES
}

\author{
G. E. J. STAAL, J. VISSER AND C. VEEGER
}

Haematological Department, The State University Hospital, Utrecht (The Netherlands) and Department of Biochemistry, Agricultural University, Wageningen (The Netherlands)

(Received January zoth, I969)

SUMMARY

I. Human erythrocyte glutathione reductase $(\mathrm{NAD}(\mathrm{P}) \mathrm{H}$ :oxidized glutathione oxidoreductase, EC I.6.4.2) was purified 47 ooo-fold by column chromatography. The enzyme contained FAD as the prosthetic group. From the flavin content a minimum mol. wt. of 56600 was calculated.

2. The mol. wt. was determined by gel filtration with Sephadex G-20o and was found to be II $5000 \pm 4000$. Blue dextran-2000 was not usable to determine the void volume of the column as it interacted with glutathione reductase.

3. The $K_{m}$ value for FAD binding to the apoenzyme was temperature dependent. The Arrhenius plot of the rate of recombination was nonlinear. Restoration of full activity occurred at least through several steps.

4. Preincubation of the apoenzyme with FMN retarded the restoration of the activity with FAD. Full restoration of the activity did not guarantee that the original enzyme conformation had been acquired.

\section{INTRODUCTION}

Glutathione reductase $(\mathrm{NAD}(\mathrm{P}) \mathrm{H}$ :oxidized glutathione oxidoreductase, EC I.6.4.2) catalyzes the reaction GSSG + NADPH $+\mathrm{H}^{+} \leftrightharpoons 2 \mathrm{GSH}+\mathrm{NADP}^{+}$; the enzyme is also active although less effective with NADH. Meldrum and TarR ${ }^{1}$ were the first to report the reduction of GSSG by NADPH catalyzed by erythrocyte preparations. Francoeur AND Denstedt ${ }^{2}$ demonstrated that both NADPH and $\mathrm{NADH}$ were effective as coenzymes in human hemolysates. ScotT et al. ${ }^{3}$ described a I 8 ooo-fold purified enzyme from erythrocytes while more recently ICÉ $\mathrm{N}^{4}$ reported a 3 I 000 -fold purification. Glutathione reductase obtained from other sources ${ }^{5-8}$ has been reported to be a flavoprotein with FAD as the prosthetic group; the enzyme from human erythrocytes is not different in this repect ${ }^{\mathbf{3 , 4}}$.

Massey AND Williams ${ }^{9}$ and Massey et al. ${ }^{10}$ pointed out the similarities between enzymes catalyzing the reduction of S-S bridges. Recent studies in our laboratory ${ }^{11}$

Abbreviation: DCIP, 2,6-dichlorophenolindophenol. 
have shown that the molecular weight of the apoenzyme of lipoamide dehydrogenase is half that of the holoenzyme; furthermore it was possible to modify lipoamide dehydrogenase by different treatments and to affect the catalytic properties.

In order to explain the decreased glutathione reductase activity in the erythrocytes of a patient with a hemolytic anemia ${ }^{\mathbf{1 2}}$, the normal as well as abnormal enzyme has been purified and characterized with respect to chemical and enzymatic properties. This paper deals with the enzyme obtained from normal human erythrocytes.

\section{MATERIALS AND METHODS}

\section{Chemicals}

$\mathrm{NADPH}, \mathrm{NADP}{ }^{+}, \mathrm{NADH}$ and $\mathrm{NAD}^{+}$were obtained from the Sigma Chemical Co. and from Boehringer and Soehne; GSSG, GSH, FAD, FMN and riboflavin from Boehringer and Soehne. DEAE-Sephadex A-5o, capacity $3.5 \pm 0.5$ mequiv/g, particle size 40-I20 $\mu$; CM-Sephadex C-5o, capacity $4.5 \pm 0.5$ mequiv $/ g$, particle size $40-\mathrm{I} 20 \mu$; and Sephadex G-20o were purchased from Pharmacia, Uppsala. Calcium phosphate gel columns were prepared according to MASSEY ${ }^{13}$. Human erythrocytes were obtained from the Central Laboratory of the Netherlands Red Cross Blood Transfusion Service, Amsterdam, The Netherlands.

\section{Determination of activity}

The assays were carried out at $25^{\circ}$ (with a Zeiss spectrophotometer PMQ II in combination with a Photovolt recorder model 43) by following the change in absorbance at $340 \mathrm{~nm}$ due to oxidation of NADPH or NADH with GSSG as an acceptor. NADPHGSSG reductase activity was determined in $0.2 \mathrm{M}$ sodium phosphate buffer ( $\mathrm{pH}$ 6.8) and $5 \mathrm{mM}$ EDTA in a final volume of $2.5 \mathrm{ml}$ containing I $\mathrm{mM}$ GSSG, I20 $\mu \mathrm{M}$ NADPH and enzyme. NADH-GSSG reductase activity was determined in $0.2 \mathrm{M}$ sodium phosphate buffer ( $\mathrm{pH} 6.3$ ) and $5 \mathrm{mM}$ EDTA in a final volume of $2.5 \mathrm{ml}$ containing I mM GSSG, I $5^{\circ} \mu \mathrm{M} \mathrm{NADH}$ and enzyme. A unit of activity is defined as the amount of enzyme required to oxidize I $\mu$ mole of $\mathrm{NAD}(\mathrm{P}) \mathrm{H}$ per min under the conditions mentioned above. The specific activity is defined as units/mg protein. The protein content was determined by the method of Lowry and Folin ${ }^{18}$ with crystalline bovine serum albumin as a standard.

\section{Molecular weight determination}

The molecular weight was estimated according to Andrews ${ }^{19}$. The reference proteins used for calibration of the column are given in Table $\mathrm{I}$.

TABLE I

REFERENCE PROTEINS USED IN THE ESTIMATION OF THE MOLECULAR WEIGHT OF GLUTATHIONE REDUCTASE

\begin{tabular}{llll}
\hline Protein & Manufacturer & Mol. $v o t$. & Ref. No. \\
\hline Pyruvate kinase & Boehringer & 237 ooo & $\mathrm{I} 4$ \\
Lactate dehydrogenase & Boehringer & $\mathrm{I} 35$ ooo & $\mathrm{I} 5$ \\
Serum albumin (human) & $\begin{array}{c}\text { Gift of Dr. R. Ballieux } \\
\text { (Utrecht) }\end{array}$ & 69000 & $\mathrm{I} 6$ \\
Chymotrypsin & Nutr. Biochem. Corp. & 25000 & $\mathrm{I} 7$ \\
\hline
\end{tabular}

Biochim. Biophys. Acta, I 85 (1969) 39-48 


\section{RESULTS}

\section{Isolation of glutathione reductase}

(I) Approx. I 1 of erythrocytes was mixed with an equal volume of water containing $50 \mathrm{ml}$ of chloroform. After standing in the cold for a few $\mathrm{h}$, the hemolysate was collected by centrifugation (Io $000 \times g$ for $30 \mathrm{~min}$ ); about 21 of hemolysate were obtained.

(2) To the hemolysate were added 21 of DEAE-Sephadex suspension prepared according to the instructions of the manufacturers, equilibrated with o.or M phosphate buffer ( $\mathrm{pH}$ 7.2) and stirred I h. The Sephadex was repeatedly washed with 0.0 I $M$ phosphate buffer ( $\mathrm{pH}$ 7.2) until the supernatant remained colorless. This procedure removed most of the hemoglobin while glutathione reductase remained bound to the Sephadex. The enzyme was eluted with $4 \mathrm{l}$ of o. I M sodium phosphate buffer $(\mathrm{pH} 7.2)$ containing $0.5 \mathrm{M} \mathrm{KCl}$.

(3) The enzyme solution obtained in the previous step was dialyzed overnight against $0.0 \mathrm{I} \mathrm{M}$ phosphate buffer ( $\mathrm{pH}$ 6.6). The enzyme from $\mathrm{I} I$ of solution was absorbed on a CM-Sephadex column $(3.5 \mathrm{~cm} \times 25 \mathrm{~cm})$ equilibrated with $0.01 \mathrm{M}$ phosphate buffer ( $\mathrm{pH}$ 6.6). The column was washed with o.or $\mathrm{M}$ phosphate buffer ( $\mathrm{pH}$ 6.6) until the eluate was colorless. The enzyme was eluted with $300 \mathrm{ml}$ of o.or $\mathrm{M}$ phosphate buffer (pH 8.o).

(4) To I200 $\mathrm{ml}$ of the enzyme solution an equal volume of DEAE-Sephadex suspension equilibrated with o.or $\mathrm{M}$ phosphate buffer ( $\mathrm{pH}$ 7.2) was added. Washing of the Sephadex and elution of the enzyme occurred in the same way as described under (2).

(5) $2100 \mathrm{ml}$ of the enzyme solution were obtained and $\left(\mathrm{NH}_{4}\right)_{2} \mathrm{SO}_{4}(35 \mathrm{O} \mathrm{g} / \mathrm{l})$ was added. The precipitate was collected by centrifuging (Io ooo $\times g$ for Io $\mathrm{min}$ ) and was suspended in $200 \mathrm{ml}$ of $\mathrm{o}$.I $\mathrm{M}$ phosphate buffer ( $\mathrm{pH} 7.2$ ). Any insoluble material was removed by centrifugation. The enzyme fraction was heated $30 \mathrm{~min}$ at $60^{\circ}$, and the precipitate was removed by centrifuging $I 5 \mathrm{~min}$ at Io $000 \times \mathrm{g}$. This procedure removed most of the red material while glutathione reductase was not inactivated (see Stability of the enzyme).

(6) The enzyme fraction obtained in the previous step was dialyzed overnight against o.or $\mathrm{M}$ phosphate buffer ( $\mathrm{pH} 7.3$ ) and was absorbed on a DEAE-Sephadex column $(2 \mathrm{~cm} \times 20 \mathrm{~cm})$ equilibrated with o.or M phosphate buffer $(\mathrm{pH} \mathrm{7.3)}$. The enzyme was eluted with $300 \mathrm{ml}$ of $0.05 \mathrm{M}$ phosphate buffer $(\mathrm{pH} 7.3)$. About $20-30 \%$ of the enzyme remained bound to the column.

(7) The enzyme was dialyzed against o.oI $\mathrm{M}$ phosphate buffer $(\mathrm{pH} 7.5)$ and absorbed on a calcium phosphate gel column, equilibrated with o.oI $\mathrm{M}$ phosphate buffer ( $\mathrm{pH} 7.5)$. The enzyme was eluted with $550 \mathrm{ml}$ of $0.03 \mathrm{M}$ phosphate buffer $(\mathrm{pH} 7.5)$.

(8) After dialyzing against o.or $\mathrm{M}$ phosphate buffer ( $\mathrm{pH} 7.5)$, the enzyme fraction was absorbed on a calcium phosphate gel column $(\mathrm{I} .5 \mathrm{~cm} \times \mathrm{I} 5 \mathrm{~cm}$ ) equilibrated with o.or $\mathrm{M}$ phosphate buffer ( $\mathrm{pH} 7.5$ ). The enzyme was eluted with I Io $\mathrm{ml}$ of $0.03 \mathrm{M}$ phosphate buffer ( $\mathrm{pH} 7 \cdot 5)$.

(9) The enzyme fraction obtained in the previous step was dialyzed against o.or $\mathrm{M}$ phosphate buffer ( $\mathrm{pH} 7.5$ ) and was absorbed on a calcium phosphate gel column ( $\mathrm{I} \mathrm{cm} \times 7.5 \mathrm{~cm}$ ), followed by elution with $25 \mathrm{ml}$ of $0.03 \mathrm{M}$ phosphate buffer $(\mathrm{pH} 7.5)$.

The whole purification procedure is summarized in Table II. 
TABLE II

\begin{tabular}{|c|c|c|c|c|c|c|}
\hline $\begin{array}{l}\text { Steps of } \\
\text { purifi- } \\
\text { cation }\end{array}$ & $\begin{array}{l}\text { Total } \\
\text { volume } \\
(\mathrm{ml})\end{array}$ & $\begin{array}{l}\text { Total protein } \\
(m g)\end{array}$ & $\begin{array}{l}\text { Total } \\
\text { activity } \\
\text { (units) }\end{array}$ & $\begin{array}{l}\text { Specific } \\
\text { activity } \\
\text { (units/mg } \\
\text { protein) }\end{array}$ & $\begin{array}{l}\text { Yield } \\
(\%)\end{array}$ & $\begin{array}{l}\text { Accumulative } \\
\text { purification } \\
\text { (-fold) }\end{array}$ \\
\hline I & 2000 & $300 \cdot 10^{3}$ & 1060 & $3 \cdot 5 \cdot 10^{-3}$ & 100 & I \\
\hline 2 & 4000 & $\mathrm{I} 2 \cdot 1 \mathrm{O}^{3}$ & 960 & $8 \cdot \mathrm{IO}^{-2}$ & 90 & 22 \\
\hline 3 & 1200 & $\mathrm{I} \cdot 32 \cdot \mathrm{IO}^{3}$ & 432 & $36 \cdot 10^{-2}$ & 40 & 102 \\
\hline 4 & 2100 & $8.82 \cdot \mathbf{I O}^{2}$ & 386 & $44 \cdot 10^{-2}$ & 36 & 125 \\
\hline 5 & 200 & $3.6 \cdot 10^{2}$ & $3^{85}$ & I. I & 35 & 3 IO \\
\hline 6 & 300 & 78 & 204 & 2.6 & 19 & 742 \\
\hline 7 & $55^{\circ}$ & I I & 132 & 12 & 12 & $34^{20}$ \\
\hline 8 & I IO & $\mathbf{I}, \mathbf{I}$ & 82 & 65 & 7 & 18500 \\
\hline 9 & 25 & 0.3 & 53 & 165 & 5 & 47000 \\
\hline
\end{tabular}

\section{Properties of the enzyme}

The purest concentrated enzyme solution is yellow and has an absorption spectrum characteristic for a flavoprotein. Maxima occur at 462,372 and $278 \mathrm{~nm}$, while there are minima at 325 and $405 \mathrm{~nm}$; near $485 \mathrm{~nm}$ a shoulder is present. The absorbance ratios for the different maxima are $A_{280 \mathrm{~nm}} / A_{462} \mathrm{~nm}=9.0$ and $A_{372 \mathrm{~nm}} / A_{462} \mathrm{~nm}=$ I.I. In Table III the values obtained by Massey AND Williams ${ }^{9}$ and Massey et al. ${ }^{\mathbf{1 0}}$ are given for the yeast enzyme and by SCOTT et $a l^{3}$ and ICÉN ${ }^{4}$ for the human erythrocyte enzyme. From this data it can be concluded that our values are in good agreement with those. FAD is the prosthetic group.

\section{TABLE III}

REFERENCE VALUES OF THE ABSORBANCY SPECTRUM AND THE MOLECULAR WEIGHT OF GLUTATHIONE REDUCTASE

\begin{tabular}{|c|c|c|c|c|c|}
\hline Source & $\begin{array}{l}\lambda_{\max } \\
(\mathrm{nm})\end{array}$ & 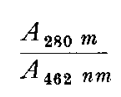 & $\begin{array}{l}\text { Mol. wt. } \\
\text { (min.) }\end{array}$ & Mol. wt. & Ref. No. \\
\hline Yeast & $\begin{array}{l}462 ; 37^{2} \\
462 ; 37^{2}\end{array}$ & $8.9: 9 \cdot 3$ & 56500 & $\begin{array}{l}\text { I I } 8000 \\
\text { I I } 8000\end{array}$ & $\begin{array}{r}9 \\
20\end{array}$ \\
\hline Erythrocyte & $\begin{array}{l}462 ; 37^{2} \\
460-462 \\
365-375 \\
462 ; 37^{2}\end{array}$ & $\begin{array}{r}\{8.8 \\
9.0\end{array}$ & $\begin{array}{r}\{6500 \\
56600\end{array}$ & $\begin{array}{l}\text { I } 32000 \\
\text { I } 5000 \\
\text { I } 25000 \\
\text { I } 5000\end{array}$ & $\begin{array}{l}3 \\
4 \\
4 \\
\text { This } \\
\text { publication }\end{array}$ \\
\hline
\end{tabular}

On the basis of the flavin content of the protein as determined spectrophotometrically and on the assumption that the molar extinction coefficient of the bound flavin is identical with that of free $\mathrm{FAD} c f$. II.3. $\mathrm{IO}^{\mathbf{3}} \mathrm{M}^{-1} \cdot \mathrm{cm}^{-1}$, for two purified enzyme preparations, a minimum mol. wt. of $56600 \mathrm{~g} /$ mole FAD could be calculated. This value agrees with those given by MASSEY AND WILLIAMs ${ }^{9}$ for the yeast enzyme and by ICÉ ${ }^{4}$ but differs from the value reported by ScotT et al. ${ }^{3}$ (Table III).

From Fig. I a mol. wt. of II5 000 ( \pm 4000 ) was calculated using the method of ANDREWS ${ }^{19}$. COLMAN AND BLACK ${ }^{20}$ reported on the basis of sedimentation-equilibrium studies a value of II 8 ooo for the mol. wt. of the yeast enzyme. More recently Mavis 


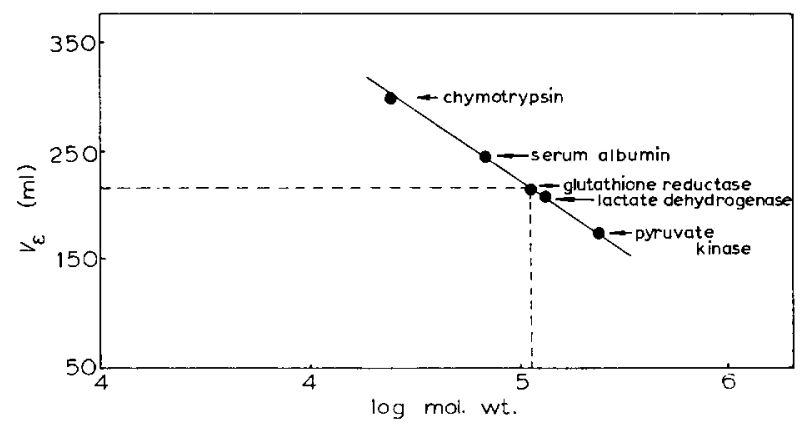

Fig. I. Estimation of the molecular weight by gel filtration on Sephadex G-2oo. Column size $3.5 \mathrm{~cm} \times 40 \mathrm{~cm}$; buffer: $0.05 \mathrm{M}$ phosphate buffer $(\mathrm{pH} 7.4)$ containing $0.5 \mathrm{M} \mathrm{KCl}$. For the reference proteins see Table I.

AND STELlWAGEN ${ }^{21}$ showed that the yeast enzyme consists of two subunits with a mol. wt. of 56000 . ICÉN ${ }^{4}$ calculated II5 000-I25000 for the human erythrocyte enzyme as determined by gel filtration. Preliminary experiments to determine the molecular weight of the apoenzyme using the gel filtration method do not indicate that the molecular weight of the apoenzyme differs from that of the holoenzyme. This is in contrast with the molecular weight of lipoamide dehydrogenase apoprotein, which is half that of the holoenzyme ( $c f$. ref. $\mathrm{II}$ ).

In the course of these studies an interesting observation was made. If blue dextran-2000 was used with a mixture of reference proteins and either glutathione reductase holoenzyme or apoenzyme to estimate the void volume of the Sephadex G-200 column, the glutathione reductase activity was found mainly in the void volume. In the absence of blue dextran, the enzyme appeared in the fraction as indicated in Fig. I. The reason for this phenomenon is not known-probably it is due to absorption of the enzyme in the dye rather than with an association of the protein. This indicates a strong interaction between this enzyme and the blue dextran polymer and suggests that blue dextran-20oo is not as inert as it is generally believed to be.

\section{Stability of the enzyme}

Glutathione reductase is very heat stable even at low concentrations. Heating I $h$ at $60^{\circ}$ in a o.I M sodium phosphate buffer $(\mathrm{pH}$ 7.2) does not lead to loss of activity. However, temperatures higher than $70^{\circ}$ lead to denaturation of the protein and result in a complete loss of activity within Io min. Addition of $\left(\mathrm{NH}_{4}\right)_{2} \mathrm{SO}_{4}$ largely protects the enzyme against heating at $72^{\circ}$ for $5 \mathrm{~min}$.

Oxidized glutathione reductase $(\mathrm{o} . \mathrm{I} \mathrm{mg} / \mathrm{ml})$ was incubated $24 \mathrm{~h}$ at $0^{\circ}$ and $25^{\circ}$ in the presence of $2,4,6$ and $8 \mathrm{M}$ urea. After $24 \mathrm{~h}$ there was no loss of activity at 2,4 and $6 \mathrm{M}$ urea at both temperatures which contrasts with the results obtained with diluted (< $<$. I $\mathrm{mg} / \mathrm{ml}$ ) lipoamide dehydrogenase ${ }^{23}$. However, no activity could be demonstrated when the enzyme was incubated with $8 \mathrm{M}$ urea under the conditions mentioned above; no difference was observed in the rate of inactivation at both temperatures. In agreement with MASSEY AND WILLIAMS ${ }^{9}$ and ICÉN ${ }^{4}$, it has been found that incubation of the enzyme in the presence of $4 \mathrm{M}$ urea and NADPH leads to complete inactivation within approx. $30 \mathrm{~min}$. 
Glutathione reductase has a low activity with 2,6-dichlorophenolindophenol (DCIP), as is the case with lipoamide dehydrogenase. When diluted glutathione reductase is dialyzed against o.or $\mathrm{M}$ phosphate buffer $(\mathrm{pH} 7.2)$ to remove EDTA and $\left(\mathrm{NH}_{4}\right)_{2} \mathrm{SO}_{4}$, it undergoes no change in activity with both GSSG and DCIP after freezing $24 \mathrm{~h}$ at $-\mathrm{r} 5^{\circ}$. This is in contrast with lipoamide dehydrogenase ${ }^{24}$ in which the DCIP activity is strongly enhanced while the lipoate activity is diminished.

\section{Preparation of the apoenzyme and recombination with $F A D$}

The apoenzyme can be prepared according to WARBURG ( $c f$. ref. 3 ); the method of STRITTMATTER ${ }^{25}$ gives the same results. The enzyme solution was $55 \%$ saturated with $\left(\mathrm{NH}_{4}\right)_{2} \mathrm{SO}_{4}$ and was brought to $\mathrm{pH}$ 3. I with I $\mathrm{M} \mathrm{HCl}$. After standing Io min in an ice bath, the apoenzyme was collected by centrifugation and was dissolved in $0.2 \mathrm{M}$ phosphate buffer ( $\mathrm{pH} 6.8$ ) containing I mM EDTA. This solution had only $8 \%$ of its original activity.

FMN and riboflavin cannot restore the enzymatic activity and only FAD is active. Fig. 2 shows the effect of the FAD concentration on the reactivation of the apoenzyme. From these data an apparent $K_{m}$ for FAD of $5 \cdot 5 \cdot 10^{-7} \mathrm{M}$ and $K_{\text {ass }}$ for $\mathrm{FAD}$ of $\mathrm{I} .8 \cdot \mathrm{IO}^{6} \mathrm{M}^{-1}$ can be calculated (a value found in three independent experiments).
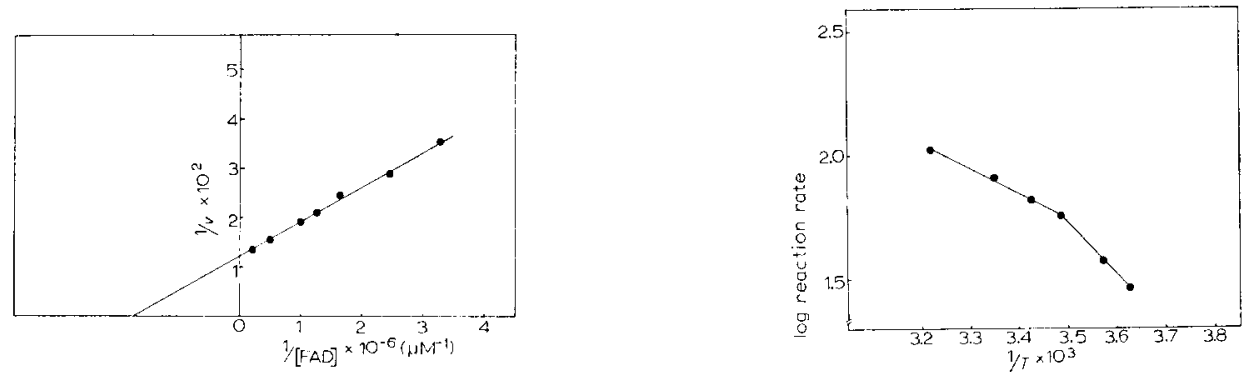

Fig. 2. Effect of FAD concentration on the reactivation of the apoenzyme by FAD. The apoenzyme was prepared as described in the text. After a 5-min incubation of $7 \mu \mathrm{g}$ apoenzyme with the concentration FAD indicated, samples were withdrawn and activities measured. $v$ is expressed as $\mu$ moles NADPH oxidized per min per mg protein.

Fig. 3. Arrhenius plot of the rate of restoration of glutathione reductase activity with FAD. Incubation mixtures $(0.25 \mathrm{ml})$ contained $5 \mu \mathrm{M} \mathrm{FAD}, 6 \mu \mathrm{g}$ apoenzyme and $0.2 \mathrm{M}$ phosphate buffer (pH 6.8). Activities were measured under standard conditions at $25^{\circ}$ after a 5 -min incubation at the given temperatures. The reaction rate is expressed as $\mu$ moles NADPH oxidized per min per mg protein.

Fig. 3 shows that the binding of FAD to the apoenzyme is a temperature-dependent process. The Arrhenius plot of the reactivation rate of the apoenzyme by FAD binding is nonlinear and shows a break at $13^{\circ}$. The activition energy for this process in the temperature range from 3 to $13^{\circ}$ is $10500 \mathrm{cal} \cdot \mathrm{mole}^{-1}$ and $5200 \mathrm{cal} \cdot \mathrm{mole} \mathrm{e}^{-1}$ in the temperature range from $I 3$ to $37^{\circ}$.

Though FMN is not capable of restoring the catalytic activity upon incubation with the apoenzyme, it is not excluded that the protein has affinity for this flavin compound. To demonstrate such interactions in flavoproteins which strongly interact with their specific flavin compound, preincubation of the apoenzyme with the aspecific 
flavin is more useful than adding both flavins. This method has been followed by VISSER AND VEEGER ${ }^{23}$ in the case of lipoamide dehydrogenase. In Fig. 4 the restoration of GSSG activity is shown upon FAD addition to an apoenzyme which was either preincubated at $0^{\circ}$ with a large amount of FMN or was not preincubated. The restoration of the activity with FAD alone is complete within $\mathrm{I} h$ after incubation on ice. Preincubation with FMN retards the restoration by FAD extensively, but ultimately the same activity level is reached. Adding FMN after the full restoration of activity by FAD leads to a decline in the activity, as shown in Fig. 4. If the same amount of FMN is added to the holoenzyme, no loss in activity is demonstrated. The insert in Fig. 4 shows that the rate of recombination (with and without preincubation with FMN) is a first-order reaction.

In Fig. 5 the restoration of GSSG activity is shown upon addition of different FAD concentrations to an apoenzyme either with or without preincubation at $0^{\circ}$ with a large amount of FMN. In the control experiment with FAD, the same $K_{m}$ values were obtained after $10,20,40$ and $60 \mathrm{~min}$ of recombination, but the $v_{\max }$ increased with the incubation time. However, after preincubation with FMN, the $K_{m}$ value for FAD altered with time and approached the $K_{m}$ value of the control.
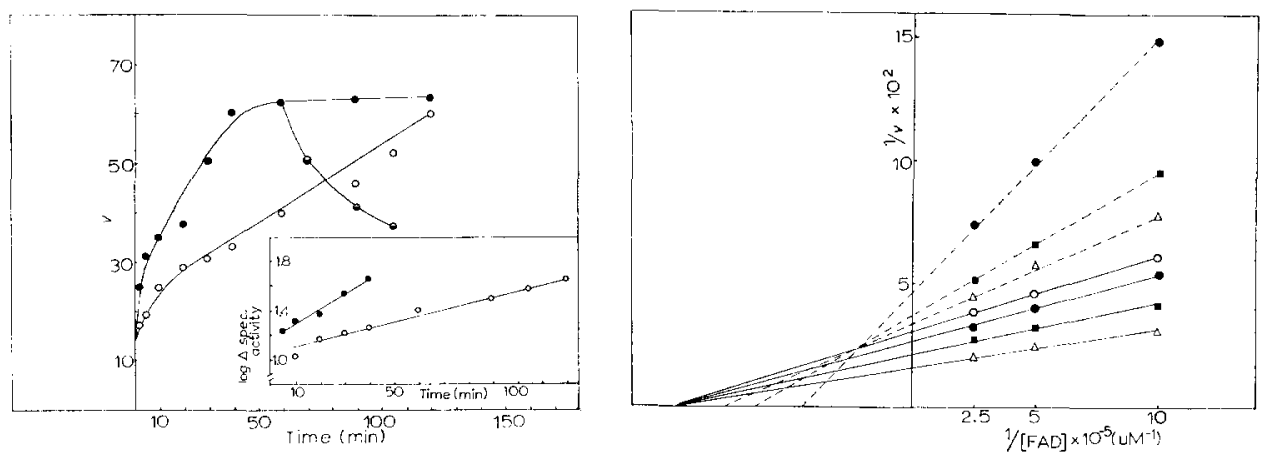

Fig. 4. Influence of FMN on the restoration of GSSG activity. $8 \mu \mathrm{M}$ FAD were added to the apoenzyme $(0.05 \mathrm{mg} / \mathrm{ml})$ at $0^{\circ}$. $\mathrm{O}-\mathrm{O}$, preincubation at $0^{\circ}$ during 30 min with $5^{\cdot} \mathrm{IO}^{-5} \mathrm{M}$ FMN; -0 , control, not preincubated with FMN; $\odot-\Theta, 5 \cdot \mathrm{IO}^{-4} \mathrm{M}$ FMN added after full restoration of activity by FAD. Samples were withdrawn at different times and the activities measured at $25^{\circ}$. The activities are expressed as $\mu$ moles NADPH oxidized per min per mg protein. Buffer: $0.2 \mathrm{M}$ sodium phosphate ( $\mathrm{pH}$ 6.8). Insert: first-order return of activity calculated from the experimental data. - , without preincubation with FMN; $\mathrm{O}-\mathrm{O}$, preincubated with FMN.

Fig. 5. Influence of FMN on the restoration of GSSG activity of the apoenzyme in the presence of different FAD concentrations at $0^{\circ}$. Activities were measured after $10(0), 20(O), 4^{\circ}(\square)$ and 6o $(\triangle)$ min of incubation with the FAD concentrations given in the figure. _ _ _ , preincubated with $5 \cdot 10^{-5}$ M FMN; - control without FMN. $v$ is expressed as $\mu$ moles NADPH oxidized per min per $m g$ protein. Buffer: $0.2 \mathrm{M}$ sođium phosphate ( $\mathrm{pH} 6.8$ ).

\section{DISCUSSION}

The human erythrocyte glutathione reductase purified by this procedure had a specific activity of 165 at $25^{\circ}$, corresponding to a 47000 -fold purification of the original hemolysate. SCOTT et al. ${ }^{3}$ obtained a value of 6 I and ICÉ $N^{4}$ of I 45 at $30^{\circ}$. The ratio of the absorbances at 280 and $460 \mathrm{~nm}(9.0)$ is similar to the ratio 8.8 reported by ICÉN ${ }^{4}$ for the human erythrocyte enzyme and to the ratios $8.9-9.3$ reported by MASSEY 
AND WILliams ${ }^{9}$ for the yeast enzyme. Our purest enzyme preparation is comparable in purity with the yeast enzyme and the enzyme preparation described by ICÉN ${ }^{4}$.

A minimum mol. wt. of 56 ooo per mole FAD could be calculated from the flavin content. This value is in good agreement with that obtained by MASSEY AND WILLIAMS ${ }^{9}$ for the yeast enzyme $\left(5^{6} 500\right)$ but differs to some extent from that reported by ICÉ $\mathrm{N}^{4}$ $(65500)$. It is clear that the value of ScotT et al. ${ }^{3}$ ( 130000$)$ is due to the low purity of the enzyme. Recently Mavis and Stellwagen ${ }^{21}$ using 5 M guanidine hydrochloride proved that the yeast enzyme contains two subunits, having a mol. wt. of $5^{\text {I }} 5^{\circ}$. In combination with the mol. wt. of II 5000 for the human erythrocyte glutathione reductase as determined by the method of ANDREws ${ }^{19}$, it can be concluded that the native enzyme contains 2 molecules of FAD and is built up by 2 polypeptide chains. This seems to be the general case for many flavoproteins, $c f$. lipoamide dehydrogenase ${ }^{23}$, D-amino-acid oxidase ${ }^{26}$, L-amino-acid oxidase ${ }^{27}$ and luciferase ${ }^{28}$.

Though lipoamide dehydrogenase and glutathione reductase seem to have many common ${ }^{29}$ properties, there are some striking differences ( $c f$. ref. $3 \mathrm{I}$ ). Up to now we could not obtain evidence that the apoenzyme of glutathione reductase is a monomer, as is the case with lipoamide dehydrogenase ( $c f$. ref. II); upon recombination of the apoenzyme with FAD, no stimulation of the DCIP activity was found as is the case with the latter enzyme ${ }^{24}$. Furthermote the results obtained from the incubation experiments with urea and the freezing and thawing experiments, do not favor the idea that the holoenzyme might dissociate into its monomers. This is in contrast with lipoamide dehydrogenase. At concentrations less than $0.1 \mathrm{mg} / \mathrm{ml}$ the dimer dissociates with the latter enzyme which leads to an increased sensitivity toward urea at low protein concentrations ${ }^{23}$.

The recombination is a temperature-dependent process as shown in Fig. 3. A possible explanation could be that the apoenzyme exists in different conformations in temperature-dependent equilibrium ( $c f$. ref. 30) with the form existing at lower temperatures having a lower association constant for $\mathrm{FAD}$ than the one present at higher temperatures $\left(>13^{\circ}\right)$. However, it cannot be concluded from these results that the part of the Arrhenius plot below $13^{\circ}$ represents the transition between the two forms ( $c f$. 1 ef. 30). An apparent difference between the Arrhenius plots of the rates of recombination process with $\mathrm{FAD}$ of glutathione reductase apoenzyme and that of lipoamide dehydrogenase is the linearity of it in the latter case. This is probably due to the completely different processes involved, e.g. FAD binding to a dimer and temperature-dependent restoration of activity in the case of glutathione reductase compared with binding of FAD to a monomer followed by temperature-dependent dimerization of the FAD containing monomer of lipoamide dehydrogenase ( $c f$. ref. II).

Though FMN cannot function as a prosthetic group it has affinity for the apoenzyme (Fig. 4). The recombination with and without preincubation with FMN proceeds in a first-order reaction which indicates that the formation of an inactive or partially active FAD-apoenzyme complex preceeds the return of a fully activated enzyme. The restoration process includes conformational changes, occuring over at least one h. FMN influences the activity of the fully restored system, while it does not influence the activity of the native holoenzyme. The formation of the holoenzyme from apoenzyme and FAD can be summarized as follows: 


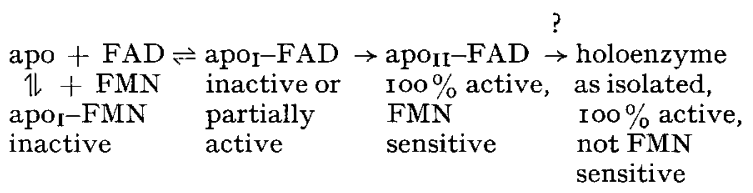

Via an inactive intermediate $\left(\mathrm{apo}_{\mathrm{I}}-\mathrm{FAD}\right)$ the fully active apo $\mathrm{II}_{\mathrm{I}}-\mathrm{FAD}$ conformation is formed. FMN can retard the formation of the apoII-FAD conformation but the reaction is almost irreversible. Therefoie only a high concentration of FMN can shift the equilibrium towards apor-FAD, apoenzyme and inactive apoI-FMN. The observation that high concentrations of FMN have no influence on the activity of the isolated enzyme indicates that an almost irreversible conformational change may occur from apo II $^{-F A D . ~ A l t h o u g h ~ t h e ~ p r e s e n t ~ e x p e r i m e n t s ~ d o ~ n o t ~ i n c l u d e ~ i n f o r m a t i o n ~}$ concerning the conversion of the FMN-sensitive apoII-FAD complex into the FMNinsensitive enzyme as isolated, such a process cannot be excluded, since it has been observed with lipoamide dehydrogenase ${ }^{23}$. The FMN-sensitive enzyme formed from lipoamide dehydrogenase apoenzyme and FAD, which is fully active with lipoate, is slowly converted into a FMN-insensitive enzyme by incubation at $25^{\circ}$ overnight. During this period no change in activity is observed. Thus a similar conversion may occur with glutathione reductase. About the nature of these conformational changes one can only speculate, but work is in progress on the nature of these interesting phenomena.

\section{ACKNOWLEDGMENTS}

The authors are indebted to Dr. M. C. Verloop, Dr. J. de Wael and P. W. Helleman for support and advice in this investigation. The authors are also grateful to Dr. R. Ballieux for the gift of human serum albumin and to Mrs. L. v. Milligen-Boersma and Mr. K. Th. Hitman for assistance.

\section{REFERENCES}

I N. Meldrum and H. Tarr, Biochem. J., 29 (i935) io8.

2 H. Francoeur and O. Denstedt, Can. J. Biochem. Physiol., 32 (1954) 663.

3 E. Scott, I. W. Duncan and V. Ekstrand, J. Biol. Chem., 238 (1963) 3928.

4 A. IcÉn, Scand. J. Clin. Lab. Invest., 20 (I967) 96.

5 R. E. Asnrs, J. Biol. Chem., 213 (I955) 77.

6 E. Racker, J. Biol. Chem., 217 (I955) 855.

7 L. W. Mapson and F. A. Isherwood, Biochem. J., 86 (I963) I73.

8 J. A. Buzard and F. Kopko, J. Biol. Chem,, 238 (1963) 464 .

9 V. M. Massey and C. H. Williams, J. Biol. Chem., 240 (1965) $447^{\circ}$.

io V. M. Massey, C. H. Williams, G. Zanetti and G. Foust, Abstr. 7th Intern. Congr. Biochem., Tokyo, I967, Symp. III, p. I65.

i I J. Visser and C. Veeger, Biochim. Biophys. Acta, I59 (I968) 265.

i 2 K. Punt, P. W. Helleman, G. E. J. Staal and M. C. Verloop, Proc. ioth Congr. European Soc. Haematol., Strasbourgh, I965, Karger, Basel, I967.

I 3 V. Massey, Biochim. Biophys. Acta, 37 (I960) 3 Io.

I 4 M. A. Steinmetz and W. C. Deal, Biochemistry, 5 (1966) 1399.

I 5 A. Pesce, F. Stolzenbach, I. Freedberg and N. O. Kaplan, Federation Proc., 22 (1963) $24 I$.

i6 H. E. Schultze and J. F. Heremans, Molecular Biology of Human Proteins, Vol. I, Elsevier, A msterdam, I966.

I 7 B. S. Hartley, Nature, 201 (1964) I284. 
is O. H. Lowry, N. J. Rosebrough, A. L. Farr and R. J. Randall, J. Biol. Chem., 193 (I95I) 265.

I9 P. ANDREws, Biochem. $J$., 96 (I965) 595.

20 R. F. Colman and S. Black, J. Biol. Chem., 240 (1965) I796.

2 I R. D. Mavis and E. Stellwagen, J. Biol. Chem., 243 (I968) 809.

22 S. Black, Ann. Rev. Biochem., 32 (I963) 399.

23 J. Visser, R. VOetberg and C. Veeger, to be published.

24 J. F. Kalse and C. Veeger, Biochim. Biophys. Acta, I 59 (I968) 244.

25 P. Strittmatter, J. Biol. Chem., 236 (I96I) 2329.

26 R. Yagi, M. Naoi, M. Harada, R. Oramura, H. Hidaka, T. Ozawa and A. Rotakt, J. Biochem., $6 \mathrm{I}$ (1967) 580.

27 A. De Kok AND A. B. Rawitz, Biochemistry, 8 (1969) I405.

28 J. Friedland and J. W. Hastings, Proc. Natl. Acad. Sci. U.S., 58 (1967) 2336.

29 V. Massey, G. Palmer, C. H. Williams, B. E. P. Swoboda and R. Sands, in E. C. Slater, Flavins and Flavoproteins, BBA Library, Vol. 8, Elsevier, Amsterdam, 1966, p. r33.

3o J. F. Koster and C. Veeger, Biochim. Biophys. Acta, i67 (1968) $4^{8}$.

3 I G. E. J. Stant ad C. Veeger, Biochim. Biophys. Acta, i 85 (I969) 49.

Biochim. Biophys. Acta, I 85 (1969) 39-48 